\title{
Elimination of toxalbumin in candlenut seed (Aleurites moluccana (L.) Willd) using wet heating at high temperature and identification of compounds in the candlenut glycoprotein
}

\author{
Mariyati Bilang $^{1}$, Mamang ${ }^{2}$, Salengke ${ }^{3}$, Reski Praja Putra ${ }^{4}$, Reta $^{5}$
}

\author{
${ }^{1}$ Department of Food Science and Technology, Hasanuddin University, Indonesia \\ 2 Center for Estate Crops Industries - Makassar, Ministry of Industry, Indonesia \\ ${ }^{3}$ Department of Agricultural Engineering, Hasanuddin University, Indonesia \\ ${ }^{4}$ Department of Agricultural Technology, Makassar State University, Indonesia \\ ${ }_{5}^{5}$ Department of Agroindustry, State Agricultural Polytechnic Pangkep, Indonesia \\ *Corresponding author's e-mail:mariyati_tekpert@yahoo.com
}

\begin{abstract}
How to Cite: Bilang, M., Mamang., Salengke., Putra, R.P., and Reta. (2018). Elimination of toxalbumin in candlenut seed (Aleurites moluccana (L.) Willd) using wet heating at high temperature and identification of compounds in the candlenut glycoprotein. Int. J. Agr. Syst. 6(2): 89-100
\end{abstract}

\begin{abstract}
Toxalbumin is a toxic glyprotein contained in candlenut seeds. This toxic compound can be removed by heat treatment before the candlenut is used in processed food products. The aim of this study was to determine the effect of wet heating at high temperatures on the toxicity of candlenut toxalbumin by examining protein profiles, amino acid and carbohytrate contens in the candlenut extract. The material used in this study was unbroken candlenut seeds. This research apply Randomize complete design. The wet hight temperature treatment of candlenut seeds in this study was carried out in autoclave followed by drying in an oven. The wet heat tretment was performed at several conditions, namely without heating as control (P0), drying in oven at $700 \mathrm{C}$ for 7 hours (P1), wet heating in autoclave at $1210 \mathrm{C}$ for 5 minutes (P2), 10 minutes (P3), 15 minutes (P4), and 20 minutes (P5). The P2, P3, P4 and P5 treatments were respectively followed by oven drying at $70 \circ \mathrm{C}$ for 7 hours. The results showed that treatment P5 reduced toxicity of candlenut toxalbumin as has been shown in other research through hemaglutination assay which indicated the abcence of aglutination of blood cells. The protein profile of candlenut extract revealed four protein bands with molecular weight of about 18-60 $\mathrm{kDa}$. The reduction of toxicity has also been indicated by the lowest intensity of the bright blue color band on the P5 treatment compared the intensities of the other bands from the other treatments. Reduction of toxicity of the toxalbumin of candlenut seeds after 20 minutes of wet heating (P5) was caused by changes in the polarity of the amino acid glycoprotein. The reduction of non polar amino acids in toxalbumin (glycoprotein) occurred during wet heating, in particular, valine and proline. The increase of glucose and fructose contents was due to the breakdown of glycosidic bonds in glycoprotein molecules.
\end{abstract}

Copyright (일 2018 IJAS. All rights reserved.

Keywords:

candlenut seed; toxalbumin glycoprotein; wet heating, toxicity 


\section{Introduction}

Candlenut plant (Aleurites moluccana (L.) Willd) belongs to the Euphorbiaceae familly, the same familly of Jatropha curcas. Candlenut have been used as a source of oil for cosmetic. However, candlenuts also contain nutrients and non-nutrients such as saponins, flavonoids, polyphenols, vitramins, folate, protein, and carbohydrates. The micronutrients contained in candlenut consisted of minerals such as potassium, phosphorus, magnesium, calcium, iron, zinc, copper and selenium. Other important compounds in candlenuts are phytosterols that can damage cholesterol-forming enzymes in the liver such that it can inhibit the formation of cholesterol in the body. Proteins in the candlenut consist of both essential and non essential amino acids. The essential and non-essential amino acids in candlenut are glutamic acid and aspartic acid. The presence of glutamic acid can provide flavor, especially when the candlenut is used as the main spice in the food, and it can substitute the function of monosodium glutamate for cooking dishes (Wiyono and Poedji, 1993).

Enev though candlenut can provide desirable functions and nutrients in food products, it also contains some undesirbale compounds such as toxalbumin that can affect blood aglutination and cause blood clotting (Aregheore et al., 1998). Toxalbumin is a phytotoxin protein (a toxin produced by plants) that can inhibit protein synthesis. Curcin and risin are toxalbumin compounds with high toxicity which are found in the seeds of Jatropha curcas and Ricinus communis, two plants that belong to the Euphorbiaceae familly. Studies on toxicity of Jatropha curcas seeds have been conducted on animal and fish by feeding jatropha nuts to the experimental animals. The results of the studies showed that the experimental animals died after several time of feedings (Adam, 1974; Ahmed and adam,1979; El Balwi at al. 1998, Aregheore et al., 1998). Examination on candlenut seed toxicity performed through hemaglutination assay indicated that candlenut toxin caused aglutination of human red bood cells (Mamang at al., 2017).

The level of toxalbumin in candlenut seed is not yet known for certain, but this compound has become one of the limiting factors for the use of candlenut in the food industry. On the other hand, the abundantcy of candlenut production is a huge potential for the development of food products and food spices in food industries, including as substitute for nut- beans such as almonds and cashews in the chocolate.

Toxalbumin in candlenut seed can be removed by heating treatment during processing or preparation of food as spices. Practices in many local communities have applied heating treatments such as burning the seed while it is still in the hard shell or frying the seed nut after removing the nut from the seed before being added as an ingredient into food formulations (Paimin, 1997). A study by Situru (unpublished internal report, 2014), showed that toxalbumin from candlenut seeds treated by dry heating treatment at temperature of $80^{\circ} \mathrm{C}$ for 10 hours and wet heating at $121^{\circ} \mathrm{C}$ for 15 minutes followed by drying at $60^{\circ} \mathrm{C}$ for 8 hours and wet heating at $121^{\circ} \mathrm{C}$ for 15 minutes followed by drying at $80^{\circ} \mathrm{C}$ for 8 hours showed negative agglutination when extracts from the samples were used in hemagglutination assay. This result shows that the activity of toxalbumin compound in the candlenut has been reduced significantly. On the other hand, dry heating at 60,80 , and $100^{\circ} \mathrm{C}$ for 8 hours did not show any effect on the toxalbumin actitity as indictaed by positive agglutination of blood cells. These results indicate that toxalbumin content in the candlenut was still high following the dry heating treatments. A study by Anggareni (unpublished internal report, 2014), however, indicated that hemagglutination assay of candlenut extracts from samples 
that have been heated at $121^{\circ} \mathrm{C}$ for 15 minutes showed negative agglutination. Aregheore et al (1998) also reported that heating of Jatropha curcas seeds at $121^{\circ} \mathrm{C}$ for 10 40 minutes caused inactivation of lectin (a glycoprotein) as indicated through hemagglutination assay.

The findings reported in literatures as depicted above clearly indicate that there is a potential in using heating treatments to reduce the toxicity of candlenut by reducing the toxicity of its toxalbumin content. Therefore, further study to examine the influence of wet heating treatment at high temperature on the toxicity of toxalbumin compounds in candlenut seeds is important. The elimination of toxic toxalbumin in candlenut seeds is of paramount importance in order to increase the safety of using candlenuts in food products and to promote wider use of this abundant commodity in food industries. The purpose of this study was to determine the effect of wet heating at high temperatures on the activity of toxalbumin in candlenut seeds. Parameters that were examined included protein profiles, protein and amino acid contents, and sugar contents.

\section{Materials and Methods}

\subsection{Experimental design}

The material used in this study was whole and dry candlenut seeds obtained from farmers in Soppeng Regency of South Sulawesi, Indonesia. The seeds were individually weighed and then heated in autoclave at predetermined temperature and duration and the experiment was conducted using Completely Randomized Design (RAL). The experimental treatments used were without heating as control (P0), heating in oven at $70^{\circ} \mathrm{C}$ for 7 hours (P1), wet heating in autoclave at $121{ }^{\circ} \mathrm{C}$ for 5 minutes (P2), 10 minutes (P3), 15 minutes (P4), and 20 minutes (P5). The treatments of P2, P3, P4 and $\mathrm{P} 5$ were respectively followed by drying in oven at $70^{\circ} \mathrm{C}$ for 7 hours.

\subsection{Chemical analysis}

Untreated candlenuts were creshed and defatted through soxhlet extraction using nhexane as solvent at a ratio of 1: 5 (wight/volume). The extraction process was conducted until the solvent become colored. After the oil extraction process, the extracts were dried to obtaine the fat-free nut powder.

\subsubsection{Preparation and isolation of glycoprotein}

Isolation of glycoprotein in the fat-free samples was done using the method employed by Luz et al. (2013). The fat-free nut powder was extracted with $0.15 \mathrm{M} \mathrm{NaCl}$ at room temperature for 6 hours. The extract obtained was precipitated with ammonium sulphate $(60 \%)$ at room temperature for 4 hours and the precipitate was centrifuged at $12,000 \mathrm{~g}$ for $20 \mathrm{~min}$ at $4 \circ \mathrm{C}$. The resulting fraction was freeze dried. The dry powder was the diluted with certain volume of $0.15 \mathrm{M} \mathrm{NaCl}$ and dialysed agains water and $0.15 \mathrm{M} \mathrm{NaCl}$ respectively for $2 \times 12$ hours. The glycoprotein fraction obtained was run through a G-75 shepadex column $(10 \mathrm{~cm} \times 1.0 \mathrm{~cm})$ which had been equilibrated using $0.1 \mathrm{M} \mathrm{NaCl}$ at flow rate of $20 \mathrm{~mL} / \mathrm{hr}$ and eluted consecutivelly with $0.3 \mathrm{M} \mathrm{NaCl}$. The elution was then freeze dried. The powder obtained from the freeze drying process was then added certain vulume of bidistilled water to dialyzed agains water containing $0.01 \% \mathrm{Na}$ acide for 12 hours and continued by freeze drying. The sample obtained from these processes was keep in air tight container for further use in analysis of protein, protein profile, amino acid and sugar contents. 


\subsubsection{Identification of Glikoprotein}

Identification of glycogen was perfomed to ensure that the extract obtained from the extraction process contained glycoprotein. Therefore, the extract should show a positive reaction for protein and carbohydrate tests. The presence of protein as well as sugar in glycoprotein molecules was qualitatively determined by color reaction using biuretical assay for proteins and Molisch reagent assay for carbohydrates.

The preparation of Biuret test for protein was done by mixing of $3 \mathrm{ml}$ of the sample solution with $1 \mathrm{ml}$ of $10 \% \mathrm{NaOH}$ solution. The mixture was then shaked to obtain homogenuous solution and then added 1-3 drops of $0.1 \% \mathrm{CuSO}_{4}$ solution and observed for the appearance of color change. The formation of purple color in the solution indicates that the sample gave a positive reaction which indicate that the sample contain protein.

The preparation of Molisch test for carbohydrates or sugars was done by mixing $1 \mathrm{ml}$ of sample solution with 2 drops of Molisch reagent then shaked ro homogenize. Thereafter, the sample was reacted with $1 \mathrm{ml}$ of $\mathrm{H}_{2} \mathrm{SO}_{4}$ by gently pouring the acid reaction to mixture through the inside wall of the test tube. A positive reaction is characterized by the appearance of a purple ring between the acid layer and the mixture layer.

\subsubsection{Determination of Protein}

The determination of protein contained in glycoprotein extract was performed using Bradford method (Bradford, 1976) with standard bovine serum albumin (BSA). Samples of glycoprotein extract with concentrations of 0.1 to $1 \mathrm{mg} / \mathrm{ml}$ solutions were resuscitated with $10 \mathrm{mM}$ of PBS. A total of $100 \mu \mathrm{l}$ of the solution was mixed with $5 \mathrm{ml}$ of Bradford reagent. The mixture was then homogenized and incubated for $5 \mathrm{~min}$ at $37^{\circ} \mathrm{C}$, then measured for absorbance at $595 \mathrm{~nm}$.

\subsubsection{Analysis of Protein profile}

Analysis of protein profile was done using the method addopted by Biosience Laboratory of State Polytechnic of Jember, Indonesia. Sodium dodecyl sulfatepolyacrylamide separation solution (SDS-PAGE) was prepared with acrylamide concentration of $12.5 \%$. The solution was added into a gel mold using a micropipette. After the gel set, stacking gel was prepared and placed in the mold. The surface of the gel was covered with a comb and then left until the stacking gel set. The gel mold was then transferred to an electrophoresis apparatus. The protein samples were added buffer solutions (0.06 M Tris HCL; 6.8, 2\% SDS, 10\% glycerol, 0.025\% bromophenol blue and $\beta$-mercaptoethanol) and heated at $100^{\circ} \mathrm{C}$ for 3 minutes. A total of $15 \mu 1$ of sample and marker (protein standard) were poured into gel wells. Electrophoresis was run until the dye reaches the end of the gel (approximately 3-4 hours). After this process, the gel was released from the mold, then immersed overnight in a brilliant blue coommasie dye solution while stirring with a shaker. The gel was then washed with a destaining solution for 15 minutes. After bands were visible, the gel was then washed with aquadest. The determination of the molecular weight of the proteins in the sample was based on the protein marker standart.

\subsubsection{Analysis of amino acids}

Amino acid analysis was performed using LC-MS according the method addopted by Biosience Laboratory of State Polytechnic of Jember, Indonesia. Glycoprotein extracts from various heat treatments were filtered with a $0.45 \mu \mathrm{m}$ PVDF filter, then injected 
into LC-MS column (Shimadzu LC-MS 2020) equipped with an AccQ.tag amino acid analysis column. Mobile phase A was water $(40 \%)$ and mobile phase B was acetonitrile $(60 \%)$. The flow rate of the mobile phase was set at $0.4 \mathrm{~mL} / \mathrm{min}$, with column temperature of $40^{\circ} \mathrm{C}$, the injection volume of sample $2 \mu \mathrm{L}$; DUIS interface (ESI - APCI); and total run time of 19 minutes.

\subsubsection{Analisis of carbohydrate}

This analysis was done to determine the type and the amount of carbohydrate (sugar) contained in the glyco molecule. The analytical procedure was performed based on the standard procedure adopted at Bioscience Laboratory of State Polytechnic of Jember. Glycoprotein extracts from various treatments were filtered with a $0.45 \mu \mathrm{m}$ PVDF filter, then injected into LC-MS (Shimadzu LC-MS 2020) under conditions: column C 18 waters; mobile phase A water $25 \%$, mobile phase B acetonitrile $75 \%$, flow rate $0.8 \mathrm{~mL}$ / min, column temperature $40^{\circ} \mathrm{C}$, injection volume $2 \mu \mathrm{L}$; DUIS interface (ESI - APCI), total runtime $7 \mathrm{~min}$, negative SIM mode $149 \mathrm{~m} / \mathrm{z}$, negative mode $179 \mathrm{~m} / \mathrm{z}$, and negative mode $341 \mathrm{~m} / \mathrm{z}$.

\subsubsection{Data analysis}

Data obtained from all the analysis conducted in this study were analyzed statistically using analysis of variance (ANOVA). If ANOVA showed significant effect of the treatments, the analysis was continued to a double Tukey Honestly Significant different double appeal test (Tukey HSD) to determine the effect of the different treatments.

\section{Results and Discussion}

\subsection{Glikoprotein content}

Glycoproteins are complex compounds between proteins and sugar that bind covantely. The results of identification of the glycoprotein in candlenut seeds are presented in Table 1. The results showed that extract samples from both the control treatment and the long wet heating treatment contain glycoprotein as shown by the formation of purple color in glycoprotein extract by Biuret test and purple ring by Molisch test. The positive results indicate the presence of protein and sugars (carbohydrates) in candlenut glycoprotein. Glycoprotein molecoles cotained in candlenut seeds are formed by proteins and carbohydrates (sugars) that bind through covalent bonds. The bonds composed of the O-links of sugar to protein and N-linked of sugar to proteins in the side of polypeptide chains.

Table 1. Results of Glycoprotein identification

\begin{tabular}{lllllllll}
\hline \multirow{2}{*}{ Test performents } & Conditon and apparent & \multicolumn{7}{c}{ Heat Treaments } \\
\cline { 3 - 8 } & & P0 & P1 & P2 & P3 & P4 & P5 \\
\hline Protein by Biuret test & Purple solution & + & + & & + & + & + & + \\
$\begin{array}{l}\text { Carbohydrate (Sugars) } \\
\text { by Molisch test }\end{array}$ & Ring purple formation & + & + & & + & + & + & + \\
\hline
\end{tabular}

Note: positive $(+)$ means the sample tested contain protein and carbohydrate. 


\subsection{Protein concentration}

The wet heating treatments followed by oven drying affected signicantly the protein content of candlenut seeds glycoprotein ( $\mathrm{p} \leq 0.05)$. Tukey test showed that protein content of candlenut glycoprotein was signinificantly different among the treatments. The wet heating treatment followed by drying caused evaporation of water from the candlenut seeds which has the potential to cause the formation of undissolved protein which in turn can lead to the reduction of protein in the glycoprotein of candlenut seeds. The changes that can occur in the protein was due to change in complex struture of the protein and in the secondary structure of the protein into a simpler struture. A study reported by Pramuditya and Yuwono (2014) indicated that the structural change of protein was mainly due to the breakdown of hydrogen bonds, ionic bonds, and by hydrophobic bonds on protein structures. Sugiharsono et al. (2014) also indicated that the heating process may lead to the occurrence of protein denaturation that leads to the change of the 3-dimensional structure of protein molecules into random structures. Heat increases the kinetic energy and causes the molecule to experience rapid vibration which under certain conditions will result in double bond damage to the long chains so that the protein splits into simpler monomers with lower molecular weight. The protein contents of sample extracts obtained from various treatments used in this study are shown in Table 2.

Table 2. Protein contents of glycoprotein of candlenut seeds as affected by wet heat treaments.

\begin{tabular}{ccc}
\hline \multirow{2}{*}{ Heat treatments } & \multicolumn{2}{c}{ Protein contents } \\
\cline { 2 - 3 } & $(\boldsymbol{\mu g} / \mathbf{\mu l})$ & $(\boldsymbol{\mu g} / \mathbf{m l})$ \\
\hline P0 & 0.215 & 215 \\
P1 & 0.205 & 205 \\
P2 & 0.155 & 155 \\
P3 & 0.107 & 107 \\
P4 & 0.115 & 115 \\
P5 & 0.100 & 100 \\
\hline
\end{tabular}

\subsection{Protein profile}

The result of electrophoresis by SDS-PAGE showed that the wet heat treatment of candlenut did not affect $(\mathrm{p} \leq 0.05)$ the protein of candlenut as indicated by the number of bands of the candlenut glycoprotein extracts (Figure 1). The results indicated all seed glycoproteins, both the control sample and the heat treated samples showed four protein bands. According to the standard used, the molecular weights of the protein constituent in candlenut seeds glyproteins were in the range of $19 \mathrm{kDa}, 38 \mathrm{kDa}, 46 \mathrm{kDa}$, and $62 \mathrm{kDa}$. 


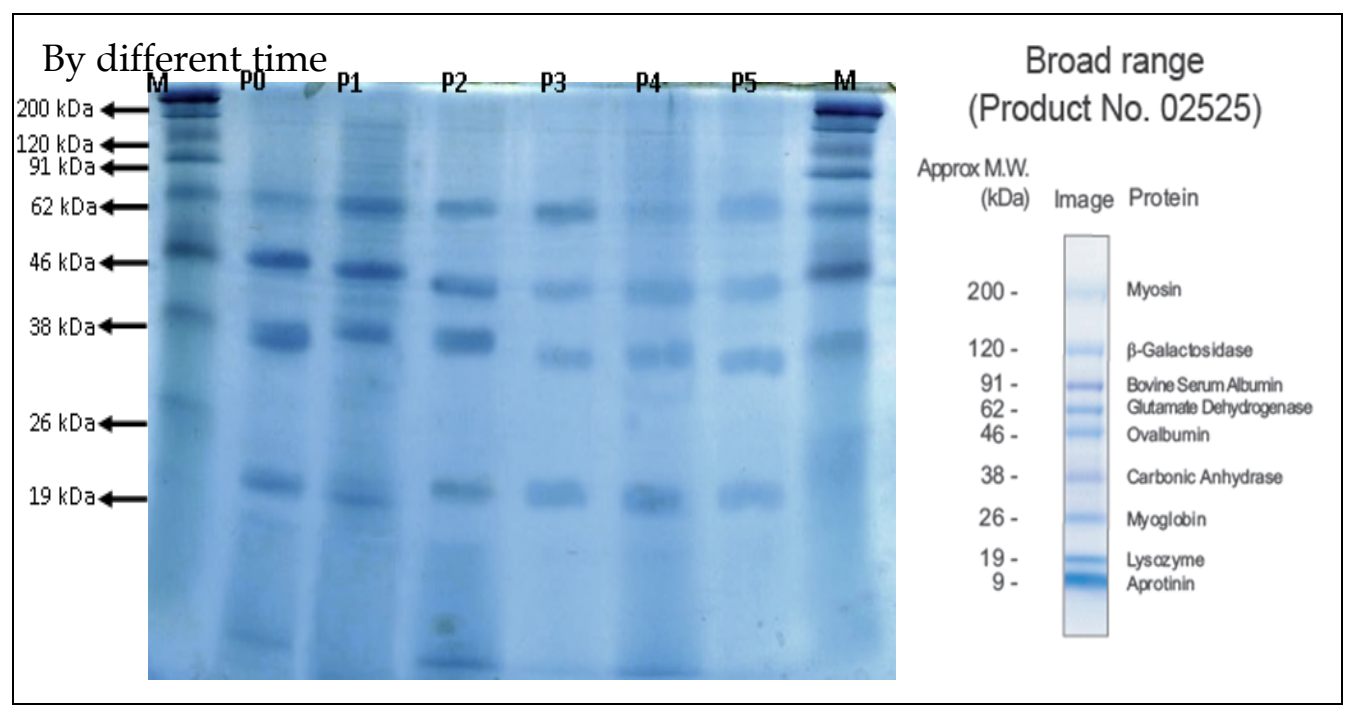

Figure 1. The bands and molecular weight of candlenut seed glycoproteins.

The results show that glycoprotein from samples that has undergone wet heating process and followed by oven drying at $70^{\circ} \mathrm{C}$ have relatively similar molecular weight, ranging from 18-60 kDa (Table 3.) According to Schep et al. (2009), the molecular weight of ricin, which is a glycoprotein from Ricinus communis was about $66 \mathrm{kDa}$. This protein comprises of a neutral A-chain $(32 \mathrm{Kda})$, bound by a disulfide bond to an acidic B-chain (34 KDA). The results of a study by Jebor and Yasser's (2012) to pure glycoproteins isolated from white beans (Phaseolus vulgaris L) revealed a single band with molecular weight of about $33 \mathrm{kDa}$. It seems that the wet heat treatment causes the decomposition of the glycoprotein compound of candlenut seed extracts into a simpler or smaller molecular structure due to the increased of kinetic energy created by heating. The change in the amino acid profile due to wet heating process followed by drying causes toxicity level of the candlenut glycoprotein to reduce and become inactive.

One of the factors that causes reduction in toxicity of the glycoprotein of the candlenut was the change in the polarity of the amino acids in the protein, especially the decrease of valine and proline amino acids. In another study by the authors, it was found that glycoprotein from candlenut can cause aglutination of human red bood cells. However, after wet heat treatment of candlenut seed, the effect of the glycoprotein on human blood aglutinanion was not observed (Mamang at al.,2017). These authors also reported that wet heating at $121^{\circ} \mathrm{C}$ for 20 minutes followed by oven drying at $70^{\circ} \mathrm{C}$ for 7 hours was able to reduce the toxicity of candlenut glycoproteins. The results showed that agglutination of human blood cells of type $\mathrm{A}, \mathrm{AB}, \mathrm{B}$, and $\mathrm{O}$ due to candlenut glycoprotein was not observed after wet-heating treatment of candlenut seeds at $121^{\circ} \mathrm{C}$ for 20 minutes followed by oven drying at $70^{\circ} \mathrm{C}$ for 7 hours. 
Table 3. Molecular weight of candlenut seed glycoproteins after heat treatments.

\begin{tabular}{ccccccc}
\hline \multirow{2}{*}{ Bands } & \multicolumn{7}{c}{ Molecular weight (kDa) } \\
\cline { 2 - 7 } & P0 & P1 & P2 & P3 & P4 & P5 \\
\hline 1 & 60 & 57 & 57 & 57 & 57 & 60 \\
2 & 46 & 45 & 41 & 41 & 41 & 45 \\
3 & 35 & 38 & 33 & 31 & 35 & 35 \\
4 & 19 & 19 & 18 & 18 & 18 & 20 \\
\hline
\end{tabular}

\subsection{Amino acids content}

Analysis of amino acids were only done on two candlenut seed samples (control and P5 treatment). This is based on the SDS PAGE analysis on amino acid profile which indicated that the band for the P5 treatment correspond to the best treament to eliminated or inactivate the toxic glycoprotein in candlenut toxalbumin. The results showed the essential amino acids in the candlenut glycoprotein consisted of leucine, isoleucine, valine, lysine, methionine, phenylalanine, and threonine. The non essential amino acids consisted of tyrosine, glutamic acid, alanine, serine, cysteine and proline (Table 4). The process of wet heating followed by drying caused changes in the amount of amino acids contained in the samples but not in the types of amino acids. In particular, the amount of valin and prolin decreased to $35.72 \%$ and $37.99 \%$ respectively. In general, the amount of amino acids in candlenut glycoprotein of wet heating treated samples were lower than those of the control (untreated ssmples). Research by Tapotubun et al. (2008) also indicated that heat-based processing in general may result in the depletion of amino acids and this change depending on the type of treatment, temperature, and length of processing. The reduction of amino acids in food products of about $10 \%$ will have a significant effect on the quality of the food (Ekop, 2008).

The main cause of the decrease of amino acids in wet heat treated samples was the change in polarity of candlenut glycoprotein. However, the decrease was also observed to occur in polar amino acids such as tyrosine $(14.07 \%)$, cysteine $(10.07 \%)$, and threonine $(7.95 \%)$. The decline of these amino acids after wet-heating process accompanied by oven drying indicated that there were changes on the complex structure and secondary structure of the nut seed protein due to changes in the chaine bonds on the glycoprotein structure. Tyrosine and threonine are amino acids containing hydroxyl groups on their side chains which play a major role in hydrogen bonds between amino acids. Cysteine is an amino acid containing sulfuhidryl groups that play a role in the formation of disulphide bridges in secondary protein structures. 
Table 4. Amino acids content of untreated and heat treated candlenut Glikoprotein.

\begin{tabular}{lcc}
\hline \multirow{2}{*}{ Types of amino acids } & \multicolumn{2}{c}{ Numbers (\%) } \\
\cline { 2 - 3 } & P0 & P5 \\
\hline Leusin-Isoleusin* & 7.715 & 7.408 \\
Valin* & 6.173 & 3.968 \\
Tirosin & 6.281 & 5.397 \\
Lisin* & 1.142 & 1.467 \\
Asam aspartate & - & - \\
Metionin* & 0.423 & 0.439 \\
Histidin & - & - \\
Asam glutamate & 2.425 & 2.174 \\
Fenilalanin* & 5.181 & 4.760 \\
Alanin & 2.888 & 2.800 \\
Serine & 0.806 & 0.977 \\
Sistein & 15.930 & 14.325 \\
Arginin & - & - \\
Treonin* & 4.739 & 4.362 \\
Prolin & 19.361 & 12.006 \\
Glisin & - & - \\
\hline
\end{tabular}

*) Essential amino acids. P0 = control (raw nut), $\mathrm{P} 5=$ Wet heating treatment at $121^{\circ} \mathrm{C}$ for 20 minuts followed by oven drying at $70^{\circ} \mathrm{C}$ for 7 hours.

The wet heating process accompanied by drying of the nut seeds was responsible for a unique phenomenon where several amino acids tended to increase such as serine $(17.50 \%)$, lysine $(22.15 \%)$, and methionine $(3.64 \%)$. Serine is one of the polar amino acids with hydroxyl groups, lysine is an alkaline amino acid with an amine group contained in the aliphatic chain, while methionine is a non-polar amino acid containing sulfur groups on its side chain. This increase of Serin, lysin and methionin was indicated by the decrease in acidity of glycoprotein. However, the opposite happened to glutamic acid, which tended to decrease to about $10.35 \%$. In addition, the wet heating process followed by drying may give rise to free amine, carboxyl, hydroxyl, and sulphuric compounds. These compounds can bind to the side chains of the amino acids serin, lysin and methionin that was resposible for the increase of these amino acids. The change of the amino acid profile after wet heating process accompanied by drying was the cause of the reduction in toxicity of the candlenut glycoprotein. One of the factors that cause reduction of toxicity was the change in the polarity of the amino acidof protein, especially the decrease of the valine and proline amino acids. 


\subsection{Sugar content}

Analysis on carbohydrate content of candlenut glycoprotein indicated that the type of sugars that are present in candle nut seed consisted of glucose, fructose, and maltose (Table 5). For this analysis, two of the six treatments (P0 and P5) were analysed for sugar content. The glycoprotein of candlenut seeds did not contain arabinose and the wet heating treatment accompanied by drying caused a change in the amount and types of sugar contained in candlenut glycoprotein.

Wet heating accompanied by oven drying led to an increase in glucose and fructose contents in the glycoprotein of candlenut but tended to lower the maltose content. The glucose content increased by $7.76 \%$ and fructose content increased by $26.82 \%$. During the wet heating process accompanied by oven drying, the carbohydrates in the glycoprotein, underwent changes from complex compounds (polysaccharides) to simpler compounds, i.e. oligosaccharides and simple sugars. This change is mainly due to the breakdown of glycosides or glycates in polysaccharides by high temperatures which caused the sugar (glucose and fructose) content increased.

Glucose in foods can be derived from the decomposition of maltose during the wet heating process. During the wet heating accompanied by drying, maltose content of glycoprotein in candlenut seeds decreased by $3.79 \%$ compared to that in control. During the process of wet heating followed by drying, glycocidic bonds in maltose breaks down and decomposed into its main components which are two molecules of glucose. The break down of the glycocidic bonds in the glycoprotein of the candlenut seed causes the toxicity of the glycoprotein to become inactive because glycoprotein breaks down into carbohydrates and proteins. The bonds between sugar (carbohydrate) and amino acids (proteins) are hydrogen bonds. The hydrogen bond is strongly influenced by temperature, where high temperature can break the hydrogen bond (Taufik 2011). This causes the sugar molecules and amino acids to separate so that the ability to absorb blood cells in hemaglutination assay is lost. Awoyinka and Dada (2011) suggested that maltose sugars do not affect hemagglutination, but fructose and glucose with increased concentrations have an inhibiting effect on the activity of glycoprotein (lectin) from Cissus popluene extract where no occurance of agglutination of blood was observed.

Table 5. Sugar content of Glycoprotein from candlenut seeds.

\begin{tabular}{lcc}
\hline \multirow{2}{*}{ Sugars } & \multicolumn{2}{c}{ Sugar content (\%) } \\
\cline { 2 - 3 } & P0 & P5 \\
\hline Glukose (\%) & 2.771 & 3.004 \\
Fruktose (\%) & 2.109 & 2.882 \\
Arabinose (\%) & - & - \\
Maltose (\%) & 4.672 & 4.495 \\
\hline
\end{tabular}




\section{Conclusions}

The wet heating treatment at $121^{\circ} \mathrm{C}$ for 20 minutes followed by drying in oven at $70^{\circ} \mathrm{C}$ for 7 hours reduced toxicity of candlenut glycoprotein. The long wet heating treatment followed by drying causesed reduction of dissolved protein in the extract of the candlenut glycoprotein. The protein profile of the soluble extract of candlenut consisted of four protein bands corresponded to molecular weight in the range of 18-60 $\mathrm{kDa}$. The profil of amino acids in candlenut glycoprotein consisted of essential and non essential amino acids. The essential amino acids consisted of leucine-isoleucine, valine, lysine, methionine, phenylalanine, and threonine, while the non-essential amino acids consisted of tyrosine, glutamic acid, alanine, serine, cysteine, and proline. Sugar profile of candlenut glycoprotein indicated that the sugars present were glucose, fructose, and maltose. The toxicity of the candlenut glycoprotein was eliminated after wet heating treatment at $121^{\circ} \mathrm{C}$ for 20 minutes followed by oven drying at $70^{\circ} \mathrm{C}$ for 7 hours due to changes in the polarity of the amino acid in the glycoprotein. The reduction of toxicity under this condition was also indicated by the decrease of the intensity of the bright blue color from the P5 sample band. The increase in glucose and fructose contents were due to the break down of glycosid bonds in glycoproteins and the decrase in polarity was primarily caused by the decrease of non polar amino acids, namely valine and proline.

\section{References}

Anggareni, A. (2014). The effects of wet and dry heating on Toxalbumin content of candlenut seeds (Aleurites moluccana). Skription (in Bahasa), Department of Food Science and Tecnology, Hasanuddin University.

Aregheore, E.M., Makkar, H.P.S and Bekker, K., (1998). Assessment of Lectin Activity in A tonic and a Non-Tonic Variety of Jatropha curcas using Latex Agglutination and haemagglutination Methods and Inactivation of Lectin by Heat Treatments. $J$ Sci Food Agric., 77: 349-352.

Awoyinka, O.A. and Dada, O.O., (2011). Partial Purification and Characterization of Lectin from the Seeds of Cissus popluena. European Journal of Medicinal Plants, 1(4): 130-139.

De Mesa, M.D., Rico E Mojica, E and E Merca Florina., (2004). Purification of Lectin from Mature Seeds of Malunggay (Moringa Pterygosperma). Philippine Journal of Crop Science, 29 (3): 13-24.

Ekop AS. 2008. Changes in amino acid composition of African yam beans (Sphenostylis stenocarpas) and African locust beans (Parkia filicoida) on cooking. Pakistan Journal of Nutrition, 5(3): 254-256.

Paimin, F.R., (1997). Candlenut: Cultivation and Business prospects. (In Bahasa). Penebar Swadaya. Jakarta.

Schep, L.J., Temple, W.A., Butt, G. A and Beasley, M.D., (2009). Ricin as a weapon of mass terror - Separating fact from fiction. Environment International, 35: 12671271. 
Situru, M. (2014). A study on the effects of wet and dry heating on Toxalbumin content of candlenut (Aleurites mollucana). Skription (in Bahasa), Department of Food Science and Tecnology, Hasanuddin University.

Sugiharsono, A. C., Dewanti, I. D. A, and Sulistyani, E. (2014). Analysis of protein profile of heat treated nimba seed extract (Azadirachta Indica A. Juzz) before extraction using SDS-PAGE. In Bahasa. Student Scientific paper, Jember University.

Tapotubun, A. M., Nanlohy E. M., and Louhenapessy, J. M. (2008). The effect of heating duration on quality of fish products. In Bahasa. Jurnal Ichthyos 7(2): 6570.

Taufik, M. (2011). A study on the potential of feet skins of broiler cheicken and its application in antibacterial adible film. Dissertation (in Bahasa). Faculty of Veterinary, Gadjah Mada university, Yogyakarta.

Wiyono, B. and Poedji, H. (1993). The effect of pretreatment of candlenut seeds on extraction yield and properties of candlenut oil. In Bahasa. Jurnal Penelitian Hasil Hutan, 11(5): 173-174. 